\title{
N-Substituted [phenyl-pyrazolo]-oxazin-2-thiones as COX-LOX inhibitors: influence of the replacement of the oxo -group with thioxo-group on the COX inhibition activity of $\mathrm{N}$-substituted pyrazolo-oxazin-2-ones
}

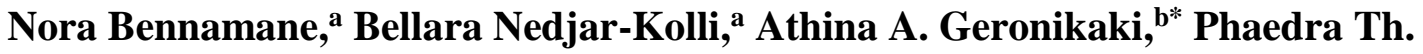 \\ Eleftheriou, ${ }^{\mathrm{c}}$ Rachedine Kaoua, ${ }^{\mathrm{a}}$ Kamal Boubekeur, ${ }^{\mathrm{d}}$ Pascal Hoffman, ${ }^{\mathrm{e}}$ Shailendra S. \\ Chaudhary, ${ }^{f}$ and Anil K. Saxena ${ }^{f}$ \\ ${ }^{a}$ Laboratory of applied organic chemistry, University of Sciences and Technology "Houari \\ Boumédiène", Algiers, Algeria \\ ${ }^{b}$ School of Pharmacy, Aristotle University of Thessaloniki, Thessaloniki 54124, Greece \\ ${ }^{c}$ Department of Medical Laboratory Studies, Alexander Technological Educational Institute of \\ Thessaloniki, Greece \\ ${ }^{d}$ Pierre and Marie Curie University, Paris, France \\ ${ }^{e}$ Paul Sabatier University, Toulouse, France \\ ${ }^{f}$ Medicinal Chemistry Division, Central Drug Research Institute, Chattar Manzil Palace, \\ Lucknow-226 001, India \\ E-mail: geronik@pharm.auth.gr
}

\begin{abstract}
Targeting to the synthesis of potent dual acting COX/LOX inhibitors as future anti-inflammatory drugs, we attempted a modification of the compounds based on docking analysis results. A substitution of the oxygen of the oxo-group of the oxazin-2-one ring by sulphur resulted in a four to over ten fold improvement of COX and LOX inhibitory action. N-phenyl derivatives exhibited the best biological properties with the 4-methoxy-phenyl derivative showing the best COX-1 and LOX inhibitory action and the 4-Br-phenyl derivative exhibiting the best COX-2 inhibitory action combined with good COX-1 and LOX inhibitory capacity.
\end{abstract}

Keywords: COX, LOX, inflammation, phenyl-pyrazolo-oxazin-2-ones, oxazin-2-thiones

\section{Introduction}

Inflammation is a multifactorial process. It reflects the response of organism to various stimuli and is related to many disorders such as arthritis, asthma, and psoriasis, which require prolonged or repeated treatment. Release of arachidonic acid via the action of phospholipase A2 on membrane phospholipids is one of the first events of inflammation. Cyclooxygenase (COX) and 
lipoxygenase (LOX) produce two groups of arachidonic acid (AA) metabolites, prostaglandins (COX products), leucotrienes and lipoxins (LOX products), that play a key role in inflammation. Traditional NSAIDs which preferentially inhibit COX-1 are associated with gastrointestinal irritation $^{1}$ and mild bleeding diathesis. NSAIDs of new generation which selectively inhibit COX-2, lack these side effects. However, some of them were associated with cardiovascular thrombotic events. ${ }^{2}$ Since COX inhibition blocks one pathway of arachidonic acid metabolism, administration of COX inhibitors leads to induction of the second pathway resulting to overproduction of leucotrienes (LTs) ${ }^{3}$ and lipoxines (LXs) via the action of LOX. LTs were found to have pro-inflammatory action. They are associated with leucocyte activation and adhesion to vascular endothelium. ${ }^{4}$ Cysteinyl LTs are associated with edema formation, damage of gastric mucosa and are involved in the pathogenesis of bronchial asthma. So, LOX products have their share in undesired inflammation events and LOX pathway has to be blocked for better results. Because leucotrienes have their role in blood coagulation and gastric tract irritation, LOX inhibition seems to be able to ameliorate GI tract irritation resulting from COX-1 inhibition as well as the prothrombotic tendency resulting from COX-2 inhibition. Thus, many researchers focused on the development of dual acting COX/LOX inhibitors. ${ }^{1,2,5}$ It has been stated that a balanced modulation of several targets can provide superior therapeutic effects and a favorable side effect profile compared to the action of a selective ligand, particularly in cases of complex diseases. ${ }^{6}$

Licofelone, a COX-2/5-LOX inhibitor, has been evaluated in a phase III clinical trial. ${ }^{7}$ Among compounds found to be potent dual inhibitors are derivatives of pyrazole, thiophene, indomethacin, dit-butyl-phenol, hydrazone, pyrrole, fenamic acid etc. ${ }^{1}$ Most recently Knaus et al. ${ }^{8}$ tested a number of 1,3-diarylprop-2-yn-1-one as well as rofecoxib derivatives for COX-1, COX-2, and 5, 15 LOX inhibitory activity. Ziakas et al. ${ }^{9}$ tested a number of tolfenamic and BHT derivatives and Geronikaki et al. tested novel thiazolidinone derivatives for COX-1, COX-2 and LOX inhibition. ${ }^{5}$

Oxazinones and pyrazole derivatives attracted organic chemists due to their biological and chemotherapeutic importance. Several benzo-oxazinones and related fused heterocycles are of interest as potential bioactive molecules. ${ }^{10-19}$ On the other hand, pyrazole and their derivatives are associated with various pharmaceutical activities..$^{20,21}$

We reported previously the synthesis and biological activity evaluation of a new series of $\mathrm{N}$ substituted pyrazolo-oxazin-2-one compounds on the basis of PASS prediction results. Positive COX-1 inhibition activity predicted by PASS was confirmed by experimental evaluation ${ }^{22}$ although the compounds exhibited only mild inhibitory action. Targeting to the synthesis of potent dual acting COX/LOX inhibitors as future anti-inflammatory drugs, we attempted a modification of the compounds based on docking results. Preliminary docking analysis revealed that substitution of the oxygen of the oxo-group of the oxazin-2-one ring by sulphur resulted in formation of a lower energy, more stable complex, in many cases.

Thione derivatives have been designed and tested by many investigators and a number of compounds with good antitumor, ${ }^{23,24}$ antimicrobial ${ }^{25,26}$ and anti-inflammatory ${ }^{26,27}$ activity have been emerged. Replacement of the oxo group by isosteric thioxo group gave rise to an increase of the biological activity in some cases. ${ }^{28-30}$ 
In the present study, seven novel thione derivatives were synthesised. All novel compounds and their oxo- analogues ${ }^{22}$ were tested for COX-1 as well as COX-2 and LOX inhibitory action.

\section{Results and Discussion}

\section{Chemistry}

The synthesis of the title compounds (Figure 1) was straightforward as illustrated in Scheme 1.

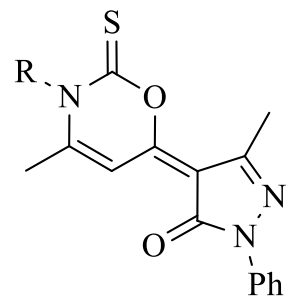
4a. $\mathrm{R}=\mathrm{C}_{2} \mathrm{H}_{5}$
4e. $\mathrm{R}=4-\mathrm{CH}_{3} \mathrm{C}_{6} \mathrm{H}_{4}$
4b. $\mathrm{R}=\mathrm{n}-\mathrm{C}_{3} \mathrm{H}_{9}$
4f. $\mathrm{R}=4-\mathrm{CH}_{3} \mathrm{OC}_{6} \mathrm{H}_{4}$
4c. $\mathrm{R}=\mathrm{C}_{6} \mathrm{H}_{5}-\mathrm{CH}_{2}$
4g. $\mathrm{R}=4-\mathrm{BrC}_{6} \mathrm{H}_{4}$
4d. $\mathrm{R}=\mathrm{C}_{6} \mathrm{H}_{5}$

Figure1. Structure of the synthesized compounds.<smiles>[R]NC(C)=CC(=O)c1c(C)nn(-c2ccccc2)c1O</smiles>

Scheme 1. Synthesis of the designed compounds.

The preparation of initial pyrazolyl-enaminone 3a-g started with reaction of commercially available dehydroacetic acid 1 with phenylhydrazine to give, in two steps, the 1,3-dicarbonyl compound $\mathbf{2}$ according to the literature procedure ${ }^{31}$. Reaction of derivatives $\mathbf{2}$ with aliphatic and aromatic primary amines lead to pyrazolyl-enaminones $3{ }^{32}$ As it was shown previously, ${ }^{22}$ in the presence of phosgene, these intermediates lead to $\mathrm{N}$-substituted pyrazolo-oxazin-2-one compounds. In similar conditions to already described procedure, ${ }^{22}$ pyrazolyl-enaminones 3 
react with thiophosgene in presence of triethylamine to give N-substituted pyrazolo-oxazin-2thione compounds 4 in 69-86\% yields (Table 1).

Table 1. N-substituted 1,3-oxazin-2-thiones $\mathbf{4 a - g}$

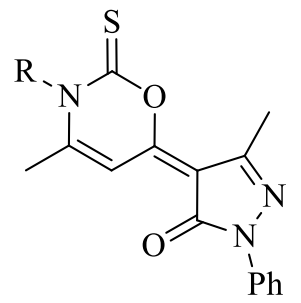

\begin{tabular}{|c|c|c|c|}
\hline Compounds & $\mathrm{R}$ & Yields (\%) & M.p. $\left({ }^{\circ} \mathrm{C}\right)$ \\
\hline $\mathbf{4 a}$ & $\mathrm{CH}_{3} \mathrm{CH}_{2}$ & 74 & 162 \\
\hline $4 b$ & $\mathrm{CH}_{3} \mathrm{CH}_{2} \mathrm{CH}_{2}$ & 71 & 195 \\
\hline $4 c$ & & 76 & 187 \\
\hline 4d & & 82 & 218 \\
\hline $4 e$ & & 86 & 200 \\
\hline $4 f$ & $\mathrm{H}_{3} \mathrm{CO}$ & 80 & 211 \\
\hline $4 g$ & $\mathrm{Br}-$ & 72 & 233 \\
\hline
\end{tabular}

The structures of compounds $\mathbf{4 a - g}$ were confirmed by elemental analysis as well as spectroscopically (IR, ${ }^{1} \mathrm{H}$ and ${ }^{13} \mathrm{C} \mathrm{NMR}$ and MS electrospray mass spectrometry).

The signal at around 177-179 ppm in ${ }^{13} \mathrm{C}$ NMR denoted the presence of the carbamate thiocarbonyl group $\mathrm{C}=\mathrm{S}$. The signals at around 158-159 and 164-165 ppm were attributed to the quaternary carbon of junction and carbonyl of pyrazolic nucleus respectively. The lack of $\mathrm{OH}$ signal in ${ }^{1} \mathrm{H}-\mathrm{NMR}$ spectra is also in accordance to the assigned structures.

All the compounds exhibit a strong thiocarbonyl $(\mathrm{C}=\mathrm{S})$ absorption in the region of 1227-1276 $\mathrm{cm}^{-1}$ of the IR spectra according to the reported value for this group ${ }^{33}$ and no absorption of the $\mathrm{OH}$ band. This is in agreement with the ring closing and the proposed structures.

The reaction mechanism could be rationalized as shown in Scheme 2. 


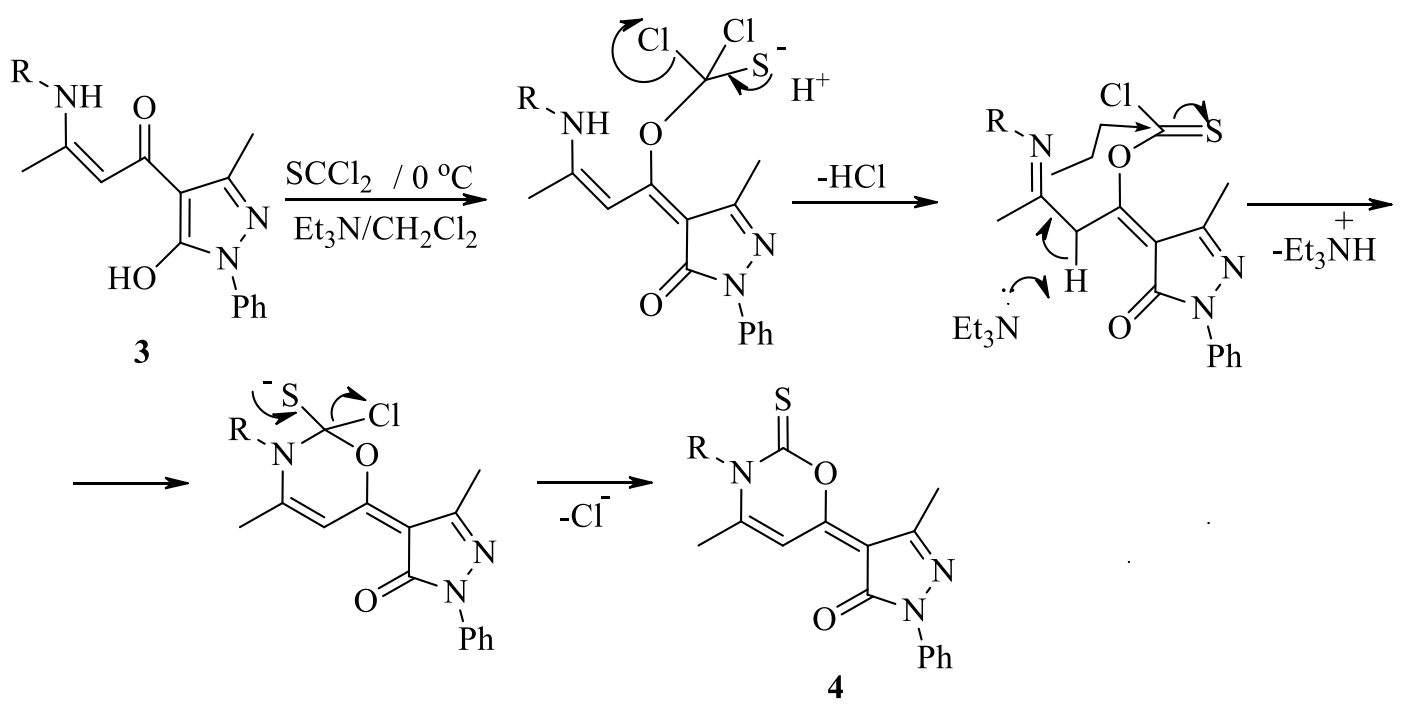

Scheme 2. Mechanism of synthetic root.

\section{Evaluation of biological activity}

Evaluation of COX-1 inhibitory action. All tested thioxo analogues exhibited COX-1 inhibitory activity, with the exception of the ethyl-derivative $4 \mathbf{a}$ and n-propyl-derivative $\mathbf{4 b}$ with $\mathrm{IC}_{50}>200 \mu \mathrm{M}$ (Table 2). Insertion of the bulky hydrophobic phenyl group in compounds $\mathbf{4 c - 4 g}$ strongly improved inhibitory action $\left(\mathrm{IC}_{50}: 6.3-25.0 \mu \mathrm{M}\right.$ ). The p-methoxy-phenyl-derivative $\mathbf{4 f}$ showed the best inhibitory activity $\left(\mathrm{IC}_{50}=6.3 \mu \mathrm{M}\right)$. The absence of the p-methoxy-group in the phenyl-derivative, $\mathbf{4 d}$, resulted in diminished activity $\left(\mathrm{IC}_{50}=17.8 \mu \mathrm{M}\right)$ while the presence of a pmethyl- substituent as well as a methylene-bridge between the phenyl and the oxazinone rings in compounds $4 \mathbf{e}$ and $4 \mathbf{c}$ further reduced inhibitory action ( $\mathrm{IC}_{50}: 21.4 \mu \mathrm{M}$ and $25.0 \mu \mathrm{M}$ respectively). Interestingly, the p-Br-phenyl derivative, $\mathbf{4 g}$, exhibited better inhibitory activity $\left(\mathrm{IC}_{50}=11.2 \mu \mathrm{M}\right)$ than the phenyl derivative, $4 \mathbf{d}\left(\mathrm{IC}_{50}=17.8 \mu \mathrm{M}\right)$. Six of the seven tested compounds present better inhibitory action than naproxen $\left(\mathrm{IC}_{50}=125.8 \mu \mathrm{M}\right)$. Comparison of the results with that previously obtained for the 1,3-oxazin-2-one analogues showed a four to over thirty fold improvement of the inhibitory activity in the 1,3-oxazin-2-thione derivatives $\mathbf{4 c - 4 g}$. Evaluation of COX-2 inhibitory action. Most compounds exhibit no COX-2 inhibitory action $\left(\mathrm{IC}_{50}>200 \mu \mathrm{M}\right.$ ) (Table 2). However, both thioxo- and oxo- 4-Br-phenyl-derivatives, $\mathbf{4 g}$, exhibited COX-2 inhibitory action with $\mathrm{IC}_{50}$ values 62 and $78 \mu \mathrm{M}$ respectively. Thioxo derivative $\mathbf{4 g}$ was slightly more active than the oxo- analogue, $\mathbf{4 g}(\mathbf{O})$, in this case, as well. 
Table 2. COX-1/2 and LOX inhibitory action of synthesized compounds and their oxo-analogues ${ }^{22}$<smiles>[R]N1C(=S)O/C(=C2\C(=O)N(c3ccccc3)N=C2C)C=C1C</smiles>

\begin{tabular}{|c|c|c|c|c|c|c|}
\hline \multirow{2}{*}{$\begin{array}{l}\text { Compounds } \\
\text { ( R ) }\end{array}$} & \multicolumn{2}{|c|}{ COX-1 $\left(\mathrm{IC}_{50}, \mu \mathrm{M}\right)^{\mathrm{a}}$} & \multicolumn{2}{|c|}{ COX-2 $\left(\mathrm{IC}_{50}, \mu \mathrm{M}\right)^{\mathrm{a}}$} & \multicolumn{2}{|c|}{$\mathrm{LOX}\left(\mathrm{IC}_{50}, \mu \mathrm{M}\right)^{\mathrm{a}}$} \\
\hline & $\begin{array}{c}\text { Thioxo- } \\
\text { derivatives }\end{array}$ & $\begin{array}{c}\text { oxo- } \\
\text { derivatives }\end{array}$ & $\begin{array}{l}\text { thioxo- } \\
\text { derivatives }\end{array}$ & $\begin{array}{c}\text { Oxo- } \\
\text { derivatives }\end{array}$ & $\begin{array}{l}\text { thioxo- } \\
\text { derivatives }\end{array}$ & $\begin{array}{c}\text { oxo- } \\
\text { derivatives }\end{array}$ \\
\hline $\mathbf{4 a}(\mathrm{Et})$ & $>200$ & $>200$ & $>200$ & $>200$ & $>200$ & $>200$ \\
\hline $4 \mathbf{b}(\mathrm{n}-\mathrm{Pr})$ & $>200$ & $>200$ & $>200$ & $>200$ & $>200$ & $>200$ \\
\hline $\begin{array}{c}\mathbf{4 c} \\
\left(\mathrm{CH}_{2} \mathrm{C}_{6} \mathrm{H}_{4}\right)\end{array}$ & 25.0 & $>200$ & $>200$ & $>200$ & $>200$ & $>200$ \\
\hline $\mathbf{4 d}(\mathrm{Ph})$ & 17.8 & 79.4 & $>200$ & $>200$ & 5.3 & 38.7 \\
\hline $\begin{array}{c}\mathbf{4 e} \\
\left(4-\mathrm{Me}-\mathrm{C}_{6} \mathrm{H}_{4}\right)\end{array}$ & 21.4 & 91.2 & $>200$ & $>200$ & 5.4 & 52.0 \\
\hline $\begin{array}{c}\mathbf{4 f} \\
\left(4-\mathrm{OMe}-\mathrm{C}_{6} \mathrm{H}_{4}\right)\end{array}$ & 6.3 & $>200$ & $>200$ & $>200$ & 3.6 & 44.2 \\
\hline $\begin{array}{c}\mathbf{4 g} \\
\left(4-\mathrm{Br}-\mathrm{C}_{6} \mathrm{H}_{4}\right)\end{array}$ & 11.2 & $>200$ & 62 & 78 & 4.2 & 27.8 \\
\hline Naproxen & 12 & 5.8 & 63 & .1 & & \\
\hline $\begin{array}{c}\text { Nordihydroguaretic } \\
\text { acid }\end{array}$ & & & & & & 3 \\
\hline
\end{tabular}

${ }^{a}$ Values are means of three determinations and deviation from the mean is $<10 \%$ of the mean value.

Evaluation of LOX inhibitory action. Thioxo derivatives 4d-g showed significant LOX inhibitory action, four to ten fold higher $\left(\mathrm{IC}_{50} 3.6-5.4 \mu \mathrm{M}\right.$ ) than the activity of their oxoanalogues ( $\mathrm{IC}_{50} 27.8-52.0 \mu \mathrm{M}$ ) (Table 2). Among the thioxo- analogues, the 4-methoxy-phenyl derivative, $\mathbf{4 f}$, exhibited the best activity $\left(\mathrm{IC}_{50}=3.6 \mu \mathrm{M}\right)$, followed by 4-Br-phenyl-, $\mathbf{4 g}$, phenyl-, 4d, and 4-methyl-phenyl, 4e, derivatives with $\mathrm{IC}_{50}$ values of $4.2 \mu \mathrm{M}, 5.3 \mu \mathrm{M}, 5.4 \mu \mathrm{M}$ 
respectively. In accordance to the COX inhibitory action, existence of the bulky phenyl moiety seams to be mandatory for LOX inhibitory activity, as well. The ethyl-, 4a, and n-propyl-, 4b, derivatives showed no inhibition. Among the compounds sharing the phenyl substituent, derivative $\mathbf{4 c}$ having a methylene-bridge between the phenyl and the oxazinone rings exhibited no activity $\left(\mathrm{IC}_{50}>200 \mu \mathrm{M}\right)$ showing that the short distance between oxazinone ring and the bulky phenyl substituent is of great importance. The better activity of 4-methoxy 4f, and 4-Br-phenyl-, $\mathbf{4 g}$, derivatives shows that existence of an electronegative atom at the 4 position of the phenyl ring favors inhibitory activity. On the contrary, the existence of a methyl group in derivative $4 \mathbf{e}$ reduced effectiveness of the inhibitor. Among, the oxo- analogues, 4-Br-derivative-, $\mathbf{4 g}(\mathbf{O})$, exhibited the best inhibitory action $\left(\mathrm{IC}_{50}=27.8 \mu \mathrm{M}\right)$, followed by 4 -methoxy derivative, $\mathbf{4 f}(\mathbf{O})$, phenyl-derivative-, $\mathbf{4 d}(\mathbf{O})$, and 4-methyl-phenyl-derivative, $4 \mathbf{e}(\mathbf{O})$, with $\mathrm{IC}_{50}=$ values $42.2 \mu \mathrm{M}$, $42.5 \mu \mathrm{M}$ and $52.0 \mu \mathrm{M}$ respectively. Existence of an electronegative atom at the 4-position of the phenyl ring seams to favor activity of the oxo- analogues as well.

In conclusion, 4-methoxy-phenyl thione derivative, $\mathbf{4 f}$ is the most effective COX-1 and LOX inhibitor but lacks COX-2 inhibitory action. 4-Br-phenyl thioxo- derivative, $\mathbf{4 g}$, effectively inhibits all three enzymes, being the second most active COX-1 and LOX inhibitor.

\section{Docking results}

Docking of the oxo- and thioxo- derivatives of compound $\mathbf{4 f}$ into the COX-1 active site are presented as an example of the influence of the oxygen to sulfur replacement in complex stabilization.

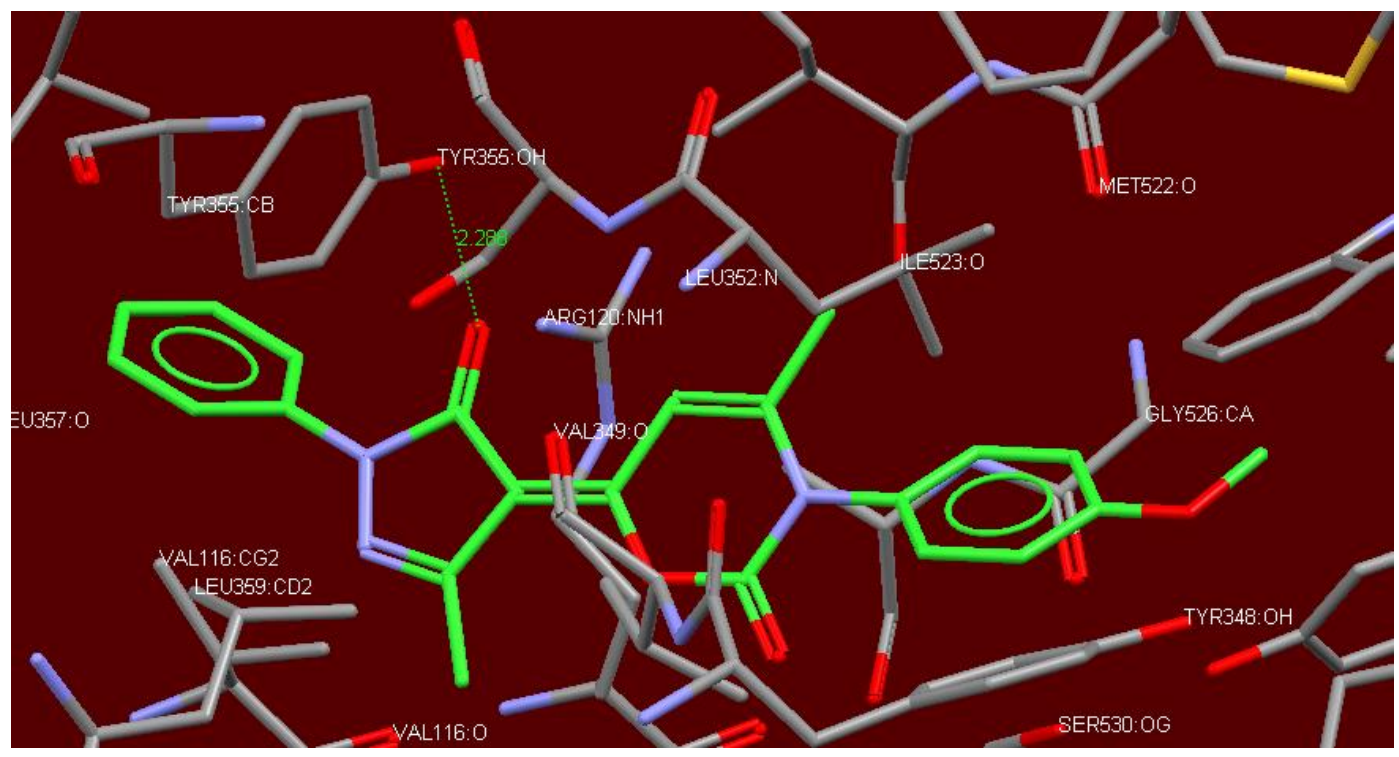

Figure.2. Docking of 4-[3-(4-methoxyphenyl) -4-methyl-2-oxo-1,3-oxazin-6-ylidene]-5-methyl2-phenyl-pyrazol-3-one, $4 \mathrm{f}(\mathrm{O})$, in the active site of COX-1.

Docking of 4-[3-(4-methoxy-phenyl)-4-methyl-2-oxo-[1,3]oxazin-6-ylidene]-5-methyl-2phenyl-pyrazol-3-one, $\mathbf{4 f}(\mathbf{O})$, revealed that the 4-methoxy phenyl group is oriented within the 
hydrophobic pocket consisting of Gly526, Val349, Tyr348, Tyr385 and Trp387, where it undergoes hydrophobic interactions with Val349, Tyr348, Trp387 (distance <4 A). The phenyl group of pyrazole ring is placed at the opening of the cleft of COX-1 binding site in close vicinity to the amino acids Leu93 and Tyr355. A hydrogen bond between the oxygen of the ketogroup of the pyrazole ring and the hydrogen of $\mathrm{OH}$ group of Tyr355 (distance=2.28 $\AA$ ) is involved in complex stabilization (Figure 2).

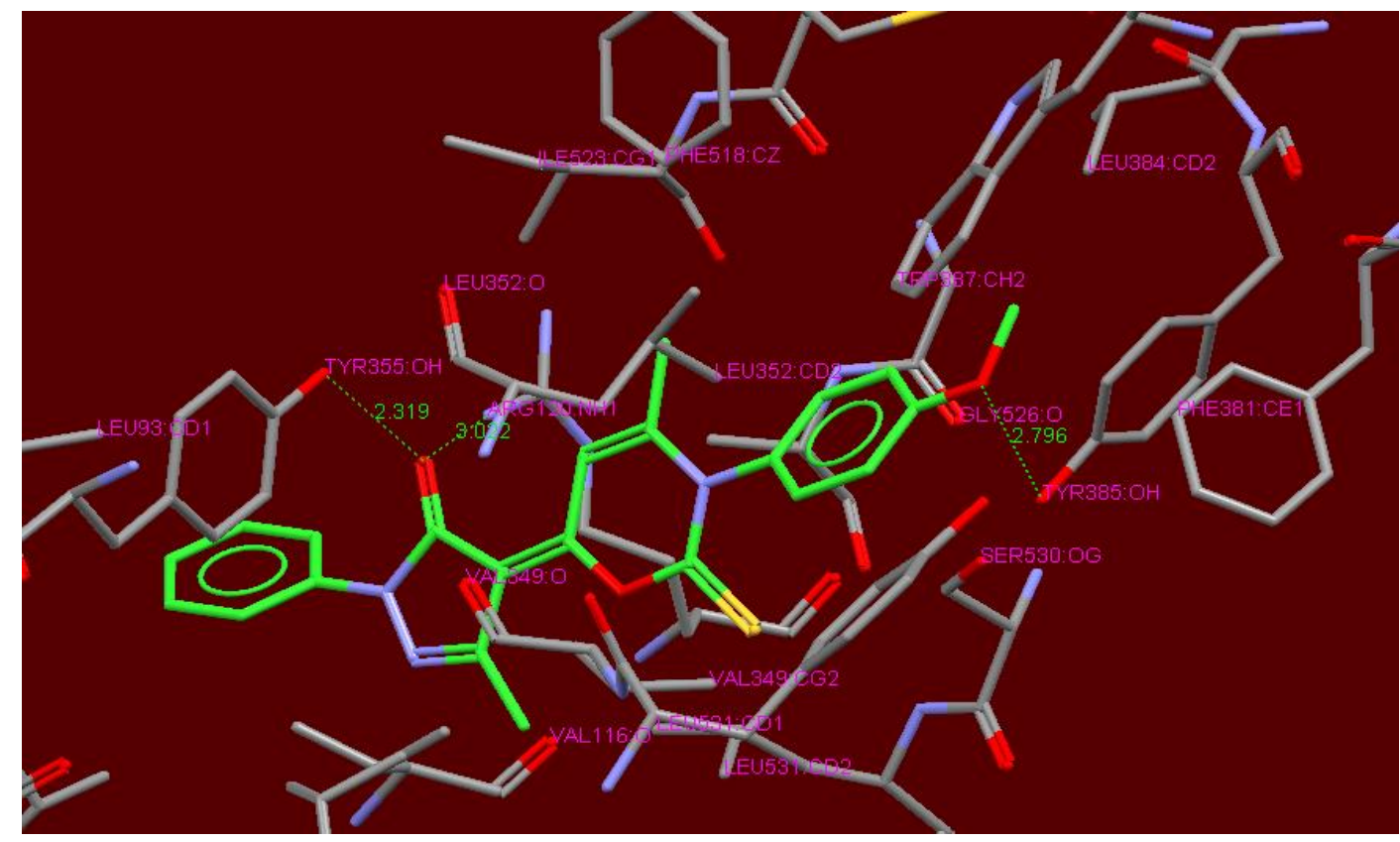

Figure 3. Docking of 4-[3-(4-methoxyphenyl) -4-methyl-2-thioxo-1,3-oxazin-6-ylidene]-5methyl-2-phenyl-pyrazol-3-one , $4 \mathrm{f}(\mathrm{S})$, in the active site of COX-1.

Docking of 4-[3-(4-methoxy-phenyl)-4-methyl-2-thioxo-[1,3]oxazin-6-ylidene]-5-methyl-2phenyl-pyrazol-3-one, $\mathbf{4 f}$, (Figure 3), the thioxo- analogue of compound $\mathbf{4 f}(\mathbf{O})$, revealed that the phenyl group of pyrazole ring is also placed at the opening of the cleft of COX-1 binding site in proximity to the amino acids Leu93 and Tyr355, where it undergoes van der Waals interaction with Tyr355 (distance $<5 \AA$ ) while the sulfur atom of oxazine ring undergoes hydrophobic interaction with Val349 of the active site. The 4-methoxy phenyl group is oriented within the hydrophobic pocket consisting of Gly526, Val349, Tyr348, Tyr385, Trp387 and Leu384. Because of a slight change in orientation of the thioxo analogue, compared to the oxo derivative, the oxygen of the 4-methoxy group participates in hydrogen bond interaction with the hydrogen of the $\mathrm{OH}$ group of Tyr385 (distance $=2.79 \AA$ ). Moreover, the slightly different position of the keto-group of the pyrazole ring in the active site, enables the formation of two hydrogen bonds (HB).One HB between the oxygen atom of the keto-group of the pyrazole ring and the hydrogen of the NH group of $\operatorname{Arg} 120$ (distance= $3.02 \AA$ ) and a second one between the oxygen atom of the same keto-group and $\mathrm{OH}$ of Tyr355 (distance $=2.31 \AA$ ) flanking the entrance of the active site. 
This difference in the number of hydrogen bonds, 3 instead of 1, may result in increased complex stability and improved inhibitory activity of the thioxo- analogue.

The ability to form hydrogen bonds with Tyr355 or Arg120 of COX-1 characterises many COX inhibitors. For example, $S$-Ibuprofen, the active isomer of the racemate used, forms three hydrogen bonds with COX-1 aminoacid remnants, one with Arg120 and two with Tyr 355. ${ }^{34}$ Tyr385, placed at the distant end of the cleft of the catalytic centre, is rarely reached by COX-1 inhibitors. Tyr385 is involved in catalytic action, since the tyrosyl radical formed is thought to be responsible for abstracting a hydrogen atom from the substrate. The tyrosyl radical produced removes hydrogen from the substrate. ${ }^{35}$ In the absence of substrate or inhibitor, Tyr385 forms a hydrogen bond with a water molecule which connects Tyr385 with Ser530 thus stabilising the molecule. The position of Tyr385 within an extremely hydrophobic neighbourhood makes any electrostatic interaction or hydrogen bond formation of great importance. ${ }^{36}$ Tyr-385/Ser-530 chelation of electron-rich centers was found to be critical for acetylation of COX-2 by aspirin and was mainly associated with time-dependent, non-covalent inhibition of COX-2 by inhibitors like diclofenac. ${ }^{37}$

\section{Conclusions}

Among the seven previously synthesized oxo analogues, only two compounds, $4 \mathbf{d}(\mathbf{O})$ and $\mathbf{4 e}(\mathbf{O})$ had been found to exhibit COX-1 inhibitory action with $\mathrm{IC}_{50}$ values lower than $200 \mu \mathrm{M}$. Evaluation of the oxo-derivatives for COX-2 and LOX inhibitory action, revealed that one of the compounds, $4 \mathbf{g}(\mathbf{O})$, exhibited mild COX-2 inhibitory action ( $\mathrm{IC}_{50}: 78.0 \mu \mathrm{M}$ ), while four of the compounds, $4 \mathbf{d}(\mathbf{O}), \mathbf{4 e}(\mathrm{O}), \mathbf{4 f}(\mathrm{O})$ and $\mathbf{4 g}(\mathbf{O})$, exhibited LOX inhibitory action $\left(\mathrm{IC}_{50}: 27.8 \mu \mathrm{M}-\right.$ $52.0 \mu \mathrm{M})$. In conclusion, three of the oxo-derivatives were found to present both COX and LOX inhibitory action. In general, the presence of a pure bulky hydrophobic group such as 4-methoxyphenyl or phenyl-group at the 3-position of the oxazinone ring $(\mathbf{4 d}(\mathbf{O}), 4 \mathbf{4 e}(\mathbf{O}))$, favored COX-1 inhibitory action. Although, replacement of the 4-methyl substituent with $\mathrm{CH}_{3} \mathrm{O}-$ or $\mathrm{Br}$ substituent resulted in reduced COX-1 inhibitory action, 4-Br- substitution favored $\mathrm{COX}-2$ as well as LOX inhibition.

Replacement of oxo- with thioxo- group strongly improved inhibitory activity of the compounds in all three enzymes. Five out of the seven tested compounds showed much better COX-1 inhibitory action (four to over thirty fold improvement), four out of seven exhibited increased LOX activity (seven to ten fold improvement) and one showed slightly improved COX-2 inhibition compared to their oxo- analogues.

The most active compounds have good inhibitory action compared to reference substances under experimental conditions and four out of the seven combine COX and LOX inhibitory action, making compounds of this series promising agents as novel dual action COX/LOX inhibitors. 


\section{Experimental Section}

General. Melting points were obtained on a Bibby stuart scientific SMP1 apparatus and are uncorrected. Elemental analyses were obtained on an acceptable range $( \pm / 0.4 \%)$ in a Perkin/Elmer 240B CHN analyzer (The Perkin-/Elmer Corporation Ltd., Lane Beaconsfield, Bucks, UK). IR spectra were recorded on a Perkin Elmer FTIR paragon 100PC spectrometer in $\mathrm{KBr}$ disks. ${ }^{1} \mathrm{H}$ NMR (400 MHz) and ${ }^{13} \mathrm{C}$ NMR (100 MHz) spectra were recorded on a Bruker Avance II spectrometer using tetramethylsilane as an internal standard,.Mass spectra were obtained by electrospray ionisation technique (ESI) on a Perkin Elmer SCIEX API 300 spectrometer.

\section{General procedure for the synthesis of compounds (4a-g)}

To a solution of enaminone $3(5 \mathrm{mmol})$ in dry dichloromethane $(50 \mathrm{ml})$ under argon atmosphere, triethylamine $(10 \mathrm{mmol})$ was added. The mixture was cooled to $0{ }^{\circ} \mathrm{C}$ and thiophosgene $(6 \mathrm{mmol})$ was added dropwise over a period of $30 \mathrm{~min}$ under magnetic stirring. The resulting mixture was then stirred for $16 \mathrm{~h}$ for compounds $\mathbf{4 a , b}$ and $12 \mathrm{~h}$ for all the others. Water was added followed by extraction with dichloromethane. The combined organic layers were dried over magnesium sulphate and evaporated to dryness. Compounds 4a-g were obtained as red solid by recrystallisation of the crude product with THF-petroleum ether (6/1).

(E)-4-(3-Ethyl -4-methyl-2-thioxo-2,3-dihydro-1,3-oxazin-6-ylidene)-3-methyl-1-phenyl-1Hpyrazol-5(4H)-one (4a). Yield 74\%, mp 162-163 ${ }^{\circ} \mathrm{C}$, IR (film, $\mathrm{cm}^{-1}$ ): 1676, 1614, 1250. ${ }^{1} \mathrm{H}$ NMR $\left(400 \mathrm{MHz}, \mathrm{CDCl}_{3}\right), \delta 1.40(\mathrm{t}, J=6.8 \mathrm{~Hz}, 3 \mathrm{H}), 2.33(\mathrm{~s}, 3 \mathrm{H}), 2.48(\mathrm{~s}, 3 \mathrm{H}), 4.29$ (q, $\left.J=6.8 \mathrm{~Hz}, 2 \mathrm{H}\right), 7.11$ 7.39 (m, 3H), 7.57 (s, 1H), 7.95 (d, $J=8 \mathrm{~Hz}, 2 \mathrm{H}) .{ }^{13} \mathrm{C} \mathrm{NMR}\left(100.6 \mathrm{MHz}, \mathrm{CDCl}_{3}\right), \delta 12.1,17.0,20.8$, 46.8, 101.8, 101.9, 118.8, 124.3, 128.6, 138.7, 147.4, 149.5, 158.6, 164.5, 177.9. MS (ESI) $\mathrm{m} / z 328$ $\left([\mathrm{M}+\mathrm{H}]^{+}, 100 \%\right)$. Anal. Calcd. for $\mathrm{C}_{17} \mathrm{H}_{17} \mathrm{~N}_{3} \mathrm{O}_{2} \mathrm{~S}: \mathrm{C}, 62.36 ; \mathrm{H}, 5.23 ; \mathrm{N}, 12.83 \%$. Found: C, 62.30; $\mathrm{H}$, $5.26 ; \mathrm{N}, 12.85 \%$.

(E)-3-Methyl-4-(4-methyl-3-propyl-2-thioxo-2,3-dihydro-1,3-oxazin-6-ylidene)-1-phenyl1H-pyrazol-5(4H)-one (4b). Yield 71\%, mp 195-195.5 ${ }^{\circ} \mathrm{C}$, IR(film, $\left.\mathrm{cm}^{-1}\right): 1673,1626,1228 .{ }^{1} \mathrm{H}$ NMR (400 MHz, $\left.\mathrm{CDCl}_{3}\right) \delta 0.99(\mathrm{t}, J=7.4 \mathrm{~Hz}, 3 \mathrm{H}), 1.77-1.86(\mathrm{~m}, 2 \mathrm{H}), 2.29$ (s, 3H), 2.48 (s, $3 \mathrm{H}), 4.09$ (t, $J=8 \mathrm{~Hz}, 2 \mathrm{H}), 7.11-7.39(\mathrm{~m}, 3 \mathrm{H}), 7.55(\mathrm{~s}, 1 \mathrm{H}), 7.96(\mathrm{~d}, J=8 \mathrm{~Hz}, 2 \mathrm{H}) .{ }^{13} \mathrm{C} \mathrm{NMR}$ $\left(100.6 \mathrm{MHz}, \mathrm{CDCl}_{3}\right), \delta 10.9,17.0,20.1,20.8,52.8,101.7,101.8,118.7,124.3,128.6,138.8$, 147.3, 149.6, 158.6, 164.5, 178.1. MS (ESI) $\mathrm{m} / \mathrm{z} 342\left([\mathrm{M}+\mathrm{H}]^{+}, 100 \%\right)$. Anal. Calcd. for $\mathrm{C}_{18} \mathrm{H}_{19} \mathrm{~N}_{3} \mathrm{O}_{2} \mathrm{~S}: \mathrm{C}, 63.32 ; \mathrm{H}, 5.61 ; \mathrm{N}, 12.31 \%$. Found: C, 62.29; H, 5.58; N, $12.31 \%$.

(E) 4-(3-Benzyl-4-methyl-2-thioxo-2,3-dihydro-1,3-oxazin-6-ylidene)-3-methyl-1-phenyl1H-pyrazol-5(4H)-one (4c). Yield 76\%, mp 187-188 ${ }^{\circ} \mathrm{C}$, IR (film, $\mathrm{cm}^{-1}$ ): 1676, 1614, 1227. ${ }^{1} \mathrm{H}$ NMR (400 MHz, $\left.\mathrm{CDCl}_{3}\right), \delta 2.22(\mathrm{~s}, 3 \mathrm{H}), 2.52$ (s, 3H), 5.56 (s, 2H), 7.13-7.39 (m, 8), 7.60 (s, 1H), 7.98 $(\mathrm{d}, J=8 \mathrm{~Hz}, 2 \mathrm{H}) .{ }^{13} \mathrm{C} \mathrm{NMR}\left(100.6 \mathrm{MHz}, \mathrm{CDCl}_{3}\right), \delta$ 17.0, 21.1, 54.5, 101.7, 102.3, 118.8, 124.4, 125.7, 128.2, 128.7, 129.2, 133.4, 138.7, 147.4, 150.1, 158.2, 164.5, 179.2. MS (ESI) $m / z .390\left([\mathrm{M}+\mathrm{H}]^{+}\right.$, $100 \%$ ). Anal. Calcd. for $\mathrm{C}_{22} \mathrm{H}_{19} \mathrm{~N}_{3} \mathrm{O}_{2} \mathrm{~S}$ : C, 67.84; H, 4.92; N, 10.79\%. Found: C, 67.87; H, 4.89; N, $10.75 \%$. 
(E)-3-Methyl-4-(4-methyl-3-phenyl-2-thioxo-2,3-dihydro-1,3-oxazin-6-ylidene)-1-phenyl1H-pyrazol-5(4H)-one (4d). Yield 82\%, mp 218-219 ${ }^{\circ} \mathrm{C}$, IR (film, $\mathrm{cm}^{-1}$ ): 1660, 1582, 1276. ${ }^{1} \mathrm{H}$ NMR (400 MHz, $\left.\mathrm{CDCl}_{3}\right), \delta 1.89$ (s, 3H), 2.53 (s, 3H), 7.13-7.58 (m, 8H), $7.74(\mathrm{~s}, 1 \mathrm{H}), 7.98(\mathrm{~d}, J$ $=8 \mathrm{~Hz}, 2 \mathrm{H}) .{ }^{13} \mathrm{C}$ NMR $\left(100.6 \mathrm{MHz}, \mathrm{CDCl}_{3}\right), \delta 17.1,21.9,100.7,102.7,118.9,124.4,127.6$, 128.7, 130.0, 130.3 138.7, 139.3, 147.4, 150.4, 158.7, 164.5, 178.6. MS (ESI) $\mathrm{m} / z .376\left([\mathrm{M}+\mathrm{H}]^{+}\right.$, $100 \%$ ). Anal. Calcd. for $\mathrm{C}_{21} \mathrm{H}_{17} \mathrm{~N}_{3} \mathrm{O}_{2} \mathrm{~S}$ : C, 67.18; H, 4.56; N, 11.19\%. Found: C, 67.23; H, 4.60; $\mathrm{N}, 11,25 \%$.

(E)-3-Methyl-4-[4-methyl-2-thioxo-3-p-tolyl-2,3-dihydro-1,3-oxazin-6-ylidene]-1-phenyl1H-pyrazol-5(4H)-one (4e). Yield 86\%, mp 200-200.5 ${ }^{\circ} \mathrm{C}$, IR (film, $\mathrm{cm}^{-1}$ ): 1665, 1589, 1276. ${ }^{1} \mathrm{H}$ NMR (400 MHz, CDCl $), \delta 1.88$ (s, 3H), 2.44 (s, 3H), 2.52 (s, 3H), 7.13-7.40 (m, 7H), $7.71(\mathrm{~s}, 1 \mathrm{H})$, $7.98(\mathrm{~d}, J=8 \mathrm{~Hz}, 2 \mathrm{H}) .{ }^{13} \mathrm{C} \mathrm{NMR}\left(100.6 \mathrm{MHz}, \mathrm{CDCl}_{3}\right), \delta 17.1,21.3,22.0,100.6,102.5,118.8,124.4$, 127.2 , 128.6, 130.9, 136.7, 138.7, 140.3, 147.4, 150.8, 158.8, 164.5, 178.8. MS (ESI) $\mathrm{m} / z 390$ $\left([\mathrm{M}+\mathrm{H}]^{+}, 100 \%\right)$. Anal. Calcd. for $\mathrm{C}_{22} \mathrm{H}_{19} \mathrm{~N}_{3} \mathrm{O}_{2} \mathrm{~S}: \mathrm{C}, 67.84 ; \mathrm{H}, 4.92 ; \mathrm{N}, 10.79 \%$. Found: C, 67.82; H, $4.94 ; \mathrm{N}, 10.82 \%$.

(E)- 4-[3-(4-Methoxyphenyl)-4-methyl-2-thioxo-2,3-dihydro-1,3-oxazin-6-ylidene]-3-methyl-1phenyl-1H-pyrazol-5(4H)-one (4f). Yield 80\%, mp 211-211.5 ${ }^{\circ} \mathrm{C}$, IR (film, $\mathrm{cm}^{-1}$ ): 1668, 1591, 1276. ${ }^{1} \mathrm{H}$ NMR (400 MHz, $\mathrm{CDCl}_{3}$ ), $\delta 1.85$ (s, 3H), 2.51 (s, 3H), 3.86 (s, 3H), 7.01-7.40 (m, 7H), $7.68(\mathrm{~s}, 1 \mathrm{H})$, $7.98(\mathrm{~d}, J=8 \mathrm{~Hz}, 2 \mathrm{H}) .{ }^{13} \mathrm{C} \mathrm{NMR}\left(100.6 \mathrm{MHz}, \mathrm{CDCl}_{3}\right), \delta 17.1,22.0,55.5,100.5,102.4,115.3,118.8$, 124.3, 128.6, 128.6, 131.9, 138.7, 147.4, 151.1, 158.8, 160.3, 164.5, 179.0. MS (ESI) $\mathrm{m} / z 406$ $\left([\mathrm{M}+\mathrm{H}]^{+}, 100 \%\right)$. Anal. Calcd. for $\mathrm{C}_{22} \mathrm{H}_{19} \mathrm{~N}_{3} \mathrm{O}_{3} \mathrm{~S}: \mathrm{C}, 65.17 ; \mathrm{H}, 4.72 ; \mathrm{N}, 10.36 \%$. Found: C, 65.21; H, $4.75 ; \mathrm{N}, 10.40 \%$.

(E)-4-[3-(4-Bromophenyl) -4-methyl-2-thioxo-2,3-dihydro-1,3-oxazin-6-ylidene]-3-methyl1-phenyl-1H-pyrazol-5(4H)-one (4g). Yield 72\%, mp 233-234 ${ }^{\circ} \mathrm{C}$, IR (film, cm $\left.{ }^{-1}\right)$ : 1664, 1585, 1268. ${ }^{1} \mathrm{H}$ NMR (400 MHz, $\mathrm{CDCl}_{3}$ ), $\delta 1.88$ (s, 3H), 2.52 (s, 3H), 7.16-7.54 (m, 7H), $7.73(\mathrm{~s}, 1 \mathrm{H})$, $7.97(\mathrm{~d}, J=8 \mathrm{~Hz}, 2 \mathrm{H}) .{ }^{13} \mathrm{C} \mathrm{NMR}\left(100.6 \mathrm{MHz} \mathrm{CDCl}_{3}\right), \delta 17.1,21.9,100.8,102.9,118.9,124.5$, 128.7, 129.1, 130.7, 136.2, 137.7, 138.7, 147.4, 149.8, 158.3, 164.5, 178.5. MS (ESI) $\mathrm{m} / \mathrm{z} 453$ $\left([\mathrm{M}+\mathrm{H}]^{+}, 100 \%\right)$. Anal. Calcd. for $\mathrm{C}_{21} \mathrm{H}_{16} \mathrm{BrN}_{3} \mathrm{O}_{2} \mathrm{~S}: \mathrm{C}, 55.51 ; \mathrm{H}, 3.55 ; \mathrm{N}, 17.59 \%$. Found: C, $55.56 ; \mathrm{H}, 3.59 ; \mathrm{N}, 17.55 \%$.

\section{Biological evaluation}

Evaluation of LOX inhibitory action. Lipoxygenase inhibition was evaluated as reported previously. ${ }^{38}$ It has been shown that inhibition of plant LOX activity by NSAIDs is qualitatively similar to the inhibition of the rat mast cell LOX and can be used as a simple screen for such activity. ${ }^{38}$ The tested compounds, dissolved in DMSO, were pre-incubated for 4 min at $28{ }^{\circ} \mathrm{C}$ with soybean lipoxygenase at a concentration of $7 \times 10^{-7} \mathrm{w} / \mathrm{v}$. Enzyme reaction was initiated by the addition of sodium linolate at a final concentration of $0.1 \mathrm{mM}$. The conversion of sodium linolate to 13-hydroperoxylinoleic acid was measured at $234 \mathrm{~nm}$. Nordihydroguaretic acid, an appropriate standard inhibitor, was used as positive control (inhibition) $94.4 \%$ at $0.1 \mathrm{mM}$ ).

COX inhibitor screening assay. The COX-1 and COX-2 activity of the compounds was measured using ovine COX-1 and human recombinant COX-2 enzymes included in the "COX 
Inhibitor Screening Assay" kit provided by Cayman (Cayman Chemical Co., Ann Arbor, MI, USA). The assay directly measures $\mathrm{PGF}_{2 \text { a }}$ produced by $\mathrm{SnCl}_{2}$ reduction of $\mathrm{COX}$-derived $\mathrm{PGH}_{2}$. The prostanoid product is quantified via enzyme immunoassay using a broadly specific antibody that binds to all the major prostaglandin compounds. ${ }^{5,9}$ The inhibitory activity of the compounds was tested at arachidonic acid concentration of $1 \mu \mathrm{M}$. The compounds were added at the reaction mixture at a final concentration of $200 \mu \mathrm{M}$ for a first screening of inhibitory action. IC $_{50}$ values were calculated for the most active compounds. Naproxen was used as a positive control.

\section{Docking analysis}

The Genetic Optimization for Ligand Docking (GOLD) version 2.2 on windows based PC, was used for docking studies ${ }^{39}$. The reported crystal structure of COX-1 (PDB code 1CQE.pdb) with co-crystal of flurbiprofen from the Brookhaven Protein Data Bank (PDB) was downloaded for the present docking study. The docked poses were scored using scoring functions: Goldscore (GS) and ChemScore (CS) to find the required docking pose. Initially, the protein was considered without ligand and water molecules for the purpose of docking studies. The proteinligand complexes of COX-1 (PDB code 1CQE.pdb) were minimized up to a gradient of 0.01 $\mathrm{kcal} /(\mathrm{mol} \AA)$ and hydrogens were added using the CHARMm force field, available in the software discovery studio 2.0 .The energy minimized structure was used for further docking analysis. In the GOLD program, the default parameters: population size (100); selection-pressure (1.1); number of operations (10,000); number of islands (1); niche size (2); and operator weights for migrate(0), mutate(100) and crossover(100) were applied. The active site was defined within $15 \AA$ and the ligand binding sites of COX-1 were analyzed. The docking of the COX-1 X-ray structure with the docking settings of flurbiprofen (reference ligand) showed hydrogen bonding between the carboxylate of the flurbiprofen with the phenolic $\mathrm{OH}$ group of Tyr355(distance=2.646 $\AA$ ) and amino group of $\operatorname{Arg} 120$ (distance $=2.835 \AA$ ). The best docked conformation in each case was taken to unravel the disparities in binding among the series of molecules.

\section{References}

1. Leval, X.; Julémont, F.; Delarge, J.; Pirotte, B.; Dogné, J-M. Curr. Med. Chem. 2002, 9, 941.

2. Altman, H.; Luciardi, L.; Muntaner, J.; Herrera, R. N. Ann. Rheum. Dis. 2003, 62, 501.

3. Penrose, J. F.; Austen, K. F.; Lam, B. K. In Inflammation basic principles and clinical correlates; Gallin, J. L.; Snyderman, R. Eds.; Lippicort Williams \& Wilkins: Philadelphia, 1999, p. 361.

4. Bray, M. A.; Ford-Hutchinson, A. W.; Smith, M. J. Prostaglandins 1981, 22, 213.

5. Geronikaki, A.; Lagunin, A.; Hadjipavlou-Litina, D.; Eleftheriou, P.; Filimonov, D.; Poroikov, V.; Alam, I.; Saxena, A. J. Med. Chem. 2008, 51,1601.

6. Morphy, R.; Rankovic, Z. J. Med. Chem. 2005, 48, 6523.

7. Bayes, M.; Rabasseda, X.; Prous, J. R. Methods Find Exp. Clin. Pharmacol. 2002, 24, 525.

8. Praveen Rao, P. N.; Chen, Q. H.; Knaus, E. E. J. Med. Chem. 2006, 49, 1668. 
9. Ziakas, G. N.; Rekka, E. A.; Gavalas, A. M.; Eleftheriou, P. T.; Kourounakis, P. N. Bioorg. Med. Chem. 2006, 14, 5616.

10. Kern, J. C.; Terefenko, E. A.; Fensome, A.; Unwalla, R.; Wrobel, J.; Zhu, Y.; Cohen, J.; Winneker, R.; Zhang, Z.; Zhang, P. Bioorg. Med. Chem. Lett. 2007, 17,189.

11. Bolognese, A.; Correale, G.; Manfra, M.; Lavecchia, A.; Mazzoni, O.; Novellino, E.; Barone, V.; La Colla, P.; Loddo, R. J. Med. Chem. 2002, 45,5217.

12. Jarvest, R. L.; Connor, S. C.; Gorniak, J. G.; Jennings, L. J.; Serafinowska, H. T.; West, A. Bioorg. Med. Chem. Lett. 1997, 7, 1733.

13. Abood, N. A.; Schretzman, L. A.; Flynn, D. L.; Houseman, K. A.; Wittwer, A. J.; Dilworth, V. M.; Hippenmeyer, P. J.; Holwerda, B.C. Bioorg. Med. Chem. Lett. 1997, 7, 2105.

14. Hsieh, P. W.; Hwang, T. L.; Wu, C. C.; Chang, F. R.; Wang, T. W.; Wu, Y. C. Bioorg. Med. Chem. Lett. 2005, 15, 2786.

15. Waisser, K.; Gregor, J.; Kubiková, L.; Klimešová, V.; Kuneš, J.; Máchaček, M.; Kaustová, J. Eur. J. Med. Chem. 2000, 35,733.

16. Hsieh, P. W.; Chang, F. R.; Chang, C. H.; Cheng, P. W.; Chiang, L. C.; Zeng, F. L.; Lin, K. H.; WU, Y. C. Bioorg. Med. Chem. Lett. 2004, 14, 4751.

17. Madhavan, G. R.; Chakrabarti, R.; Reddy, K. A.; Rajesh, B. M.; Balaju, V.; Rao, P. B.; Rajagopalan, R.; Iqbal, J. Bioorg. Med. Chem. 2006, 14, 584.

18. Colson, E.; Wallach, J.; Hauteville, M. Biochimie 2005, 87, 223.

19. Atkinson, P. J.; Bromidge, S. M.; Duxon, M. S.; Gaster, L. M. Hadley, M. S.; Hammond, B.; Johnson, C. N.; Middlemiss, D. N.; North, S. E.; Price, G. W.; Rami, H. K.; Riley, G. J.; Scott, C. M.; Shaw, T. E.; Starr, K. R.; Stemp, G.; Thewlis, K. M.; Thomas, D. R.; Thompson, M.; Vong, A. K.; Watson, J. M. Bioorg. Med. Chem. Lett. 2005, 15,737.

20. Shaharyar, M.; Siddiqui, A. A.; Ali, M. A.; Sriram, D.; Yogeeswari, P. Bioorg. Med. Chem. Lett. 2006, 16, 3947.

21. Gürsoy, A.; Demirayak, S.; Capan, G.; Erol, K.; Vural, K. Eur. J. Med. Chem. 2000, 35, 359.

22. Benaamane, N.; Nedjar-Kolli, B.; Bentarzi, Y.; Hammal, L.; Geronikaki, A.; Eleftheriou, P.; Lagunin, A. Bioorg. Med. Chem. 2008, 16, 3059.

23. Aboraia, A. S.; Abdel-Rahman, H. M.; Mahfouz, N. M.; El-Gendy, M. A. Bioorg. Med. Chem. 2006, 14, 1236.

24. Saczewski, J.; Brzozowski, Z.; Saczewski, F.; Bednarski, P. J.; Liebeke, M.; Gdaniec, M. Bioorg. Med. Chem. Lett. 2006, 16, 3663.

25. Ozçelik, A. B.; Ersan, S.; Ural, A. U.; Ozkan, S.; Ertan, M. Arzneimittelforschung 2007, 57, 554.

26. Salgin-Gökşen, U.; Gökhan-Kelekçi, N.; Göktaş, O.; Köysal, Y.; Kiliç, E.; Işik, S.; Aktay, G.; Ozalp, M. Bioorg. Med. Chem. 2007, 15, 5738.

27. Burbuliene, M. M.; Jakubkiene, V.; Mekuskiene, G.; Udrenaite, E.; Smicius, R.; Vainilavicius, P. Farmaco 2004, 59, 767.

28. Agirba, A.; Sagdinc, S.; Kandemirly, F.; Ozturk, D. J. Mol. Struct. 2007, 830, 116.

29. Waisser, K.; Kubicova, L.; Kaustova, J.; Bartsh, H.; Ekker, T. Sci. Pharm. 1999, 67,123. 
30. Waisser, K.; Gregor, J.; Kubicova, L.; Klimsova, V.; Kunes, J.; Machacek, M. Kaustova, J. Eur. J. Med.Chem. 2000, 35,733.

31. Gelin, S.; Chantegrel, B.; Nadi, A. I. J. Org. Chem. 1983, 48, 4078.

32. Bendaas, A.; Hamdi, M.; Sellier, N. J. Heterocyclic Chem. 1999, 36, 1291.

33. Mazharuddin, M.; Thyagarajan, G. Tetrahedron 1969, 25, 517.

34. Mittal, S.; Malde, A.; Selvam, C.; Arun, K. H. S.; Johar, P. S.; Jachak, S. M.; Ramarao, P.; Bharatam P. V.; Chawla H. P. S. Bioorg. Med. Chem. Lett. 2004, 14, 979.

35. Smith, W. L.; Eling, T. E.; Kulmacz, R. J.; Marnett, L. J.; Tsai, A. Biochemistry 1992, 31, 3.

36. Selinsky, B. S.; Gupta, K.; Sharkey, C. T.; Loll, P. J. Biochemistry 2001, 40, 5172.

37. Rowlinson, S. W.; Kiefer, J.R.; Prusakiewicz, J. J.; Pawlitz, J. L.; Kozak, K. R.; Kalgutkar, A. S.; Stallings, W. C.; Kurumbail, R. G.; Marnett, L .J. J. Biol. Chem. 2003, 278, 45763.

38. Hadjipavlou-Litina, D. J. Geronikaki, A. Drug Des. Discovery 1999, 15, 199.

39. GOLD, version 2.2; Cambridge Crystallographic Data Centre: Cambridge, UK. 